\title{
An Empirical Analysis to Determine Poverty as Key Issue of Fewer Enrollments: e-Learning as the Best Remedy to Enhance GER of Higher Studies in West Bengal
}

\author{
Anirban Das and Subir Gupta
}

\begin{abstract}
According to the investigated data of higher education ministry of West Bengal, the GER of West Bengal in higher education is $\mathbf{2 6 . 2 3 \%}$. Most of the dropout students have shown poverty as a ground for which they are unable to carry on higher education even getting admired to it. In this paper an approach is followed through which poverty is determined as a significant factor along with other factors in less enrollments in higher education in West Bengal and distribution of funds all the way through electronic-monitoring founded on web enabled applications may be one of the best remedies to eradicate poverty so that the already dropped out candidates or candidates just going to be dropped out can be lessen and gradually the Gross Enrollment Ratio (GER) in higher education of West Bengal will enhance.
\end{abstract} GER

Index Terms-Dropout, e-learning, e-monitoring, enrollment,

\section{INTRODUCTION}

Considering the different factors those are accountable for the dropouts in higher education in West Bengal we get the factors are like, poverty, expensive higher education, distance from higher education institutes and residence, limited seats in higher education institutes, early marriage, no secured job or prospect after completion of higher education, no such opportunities for mediocre students, becoming earning member to family etc. Of these factors, poverty is the most considerable reason as has been reflected in survey in remote regions of West Bengal.

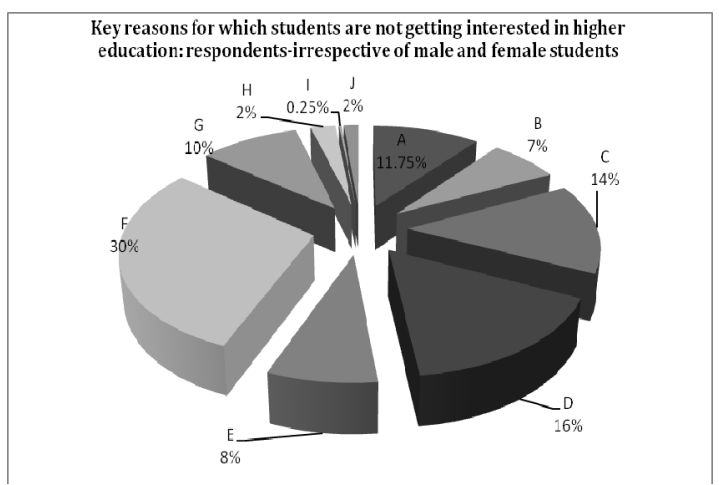

Fig. 1. Factors responsible for students' less interests on higher education enrolments in West Bengal.[1]

Manuscript received July 5, 2011; revised October 22, 2011.

Authors are with Department of Computer Applications, Dr. B. C. Roy Engineering College, Durgapur, India (e-mail: anirban-das@live.com, g_subir@rediffmail.com; Phone: +919474623504, +919477462400).
$\mathrm{A}=$ Improper guidance on higher education leads them least interested to it

$\mathrm{B}=$ Less number of higher education institutes

$\mathrm{C}=$ No secured job after doing higher education

$\mathrm{D}=$ opportunity for average or below average students is not present in higher education

$\mathrm{E}=$ expensive higher education

$\mathrm{F}=$ poverty

$\mathrm{G}=$ Limited seats for desired subjects in higher education institutes

$\mathrm{H}=$ early marriage

$\mathrm{I}=$ Distance from home to higher education institutes and bad transportation

$\mathrm{J}=$ They become earning member of family

From students' response data it is transparent that poverty is a key factor for less enrollments in higher education in West Bengal as mostly one third student pool opined in favor of poverty.

\section{Methodologies And Results}

An empirical approach was taken place in 8 districts of West Bengal. In each and every district 5 schools (schools are categorized like, rural, semi urban and urban) were selected and from each school only 10 below secondary or secondary students, who are going to face secondary examination, are selected as sample respondent i.e. primary respondent at a random basis. Besides, some associated teachers' and parents' comments are also entertained.

As we have emphasized on the major most factor poverty for less enrollments in higher education, the reasons of poverty is also collected from respondents like big population of family, less education of family members, irregularity of job because of physical unfitness hamper daily family maintenance. Reasons may also be considered as have been reflected from the survey as non-availability of work, price effect, non adequate medical facilities, uncertainty of job, weather effects etc. In order to identify the main indicators of poverty, several surveys are conducted in different remote villages and depending on their comments we have conducted multiple correlation and coefficient of variance analysis. And, based on the analysis we have identified key factors which are responsible for measuring poverty in remote villages in West Bengal. 
TABLE I: KEY PARAMETERS RESPONSIBLE FOR POVERTY

\begin{tabular}{|c|c|}
\hline Reasons of poverty & Coefficient of variances \\
\hline Big population of family & 59.64 \\
\hline Less education of family & 15.6827 \\
\hline $\begin{array}{c}\text { Irregularity of work / job due } \\
\text { to physical unfitness hampers } \\
\text { daily family maintenance }\end{array}$ & 44.0958 \\
\hline $\begin{array}{c}\text { Irregularity of work / job due } \\
\text { to scope/availability of work }\end{array}$ & 19.6295 \\
\hline Price effect & 9.9804 \\
\hline Inadequate medical facilities & 38.56 \\
\hline Uncertainty weather effects & 55.076 \\
\hline
\end{tabular}

In reference to the TABLE 1 and Fig 1 we have considered the following parameters as key indicators of poverty in West Bengal like less education of family, irregularity of work / job due to scope/availability of work and price effect.

To make this analysis more significant we have also relied on multiple correlation analysis to identify the main parameters for measuring poverty in remote areas of West Bengal.

TABLE II: IDENTIFICATION OF MAIN PARAMETERS RESPONSIBLE FOR POVERTY THROUGH MULTIPLE CORRELATION ANALYSIS

\begin{tabular}{|c|c|c|c|c|}
\hline $\begin{array}{c}\text { Selected } \\
\text { parameters } \\
\text { for } \\
\text { measuring } \\
\text { poverty }\end{array}$ & $\begin{array}{c}\text { Pearson's } \\
\text { correlation/ } \\
\text { test of } \\
\text { hypothesis }\end{array}$ & $\begin{array}{c}\text { Less } \\
\text { educat } \\
\text { ion of } \\
\text { family }\end{array}$ & $\begin{array}{c}\text { Irregularity } \\
\text { of work / job } \\
\text { due to scope } \\
\text { /availability } \\
\text { of work }\end{array}$ & $\begin{array}{l}\text { Price } \\
\text { effect }\end{array}$ \\
\hline \multirow{3}{*}{$\begin{array}{c}\text { Less } \\
\text { education of } \\
\text { family }\end{array}$} & $\begin{array}{r}\text { Pearson } \\
\text { Correlation }\end{array}$ & 1 & $.459(*)$ & 035 \\
\hline & $\begin{array}{c}\text { Sig. } \\
\text { (1-tailed) }\end{array}$ & . & .032 & 446 \\
\hline & $\mathrm{N}$ & 50 & 50 & 50 \\
\hline \multirow{3}{*}{$\begin{array}{c}\text { Irregularity } \\
\text { of work / job } \\
\text { due to } \\
\text { scope/availa } \\
\text { bility of } \\
\text { work }\end{array}$} & $\begin{array}{r}\text { Pearson } \\
\text { Correlation }\end{array}$ & $459(*)$ & 1 & 188 \\
\hline & $\begin{array}{c}\text { Sig. } \\
\text { (1-tailed) }\end{array}$ & 032 & . & 235 \\
\hline & $\mathrm{N}$ & 50 & 50 & 50 \\
\hline \multirow[t]{3}{*}{ Price effect } & $\begin{array}{r}\text { Pearson } \\
\text { Correlation }\end{array}$ & 035 & .188 & 1 \\
\hline & $\begin{array}{c}\text { Sig. } \\
\text { (1-tailed) }\end{array}$ & 446 & .235 & . \\
\hline & $\mathrm{N}$ & 50 & 50 & 50 \\
\hline
\end{tabular}

From TABLE II, it can be standardized that to eradicate poverty the already mentioned factors are to be taken care of.

An electronic web based model of e-monitoring system can be developed targeting to eradicate poverty from West Bengal such as, through the e-monitoring systems from each and every block it is possible to know due to which factor that very block is affected with poverty like, flood affected zone, draught affected zone, hill areas, tsunami affected zone, seasonal storm or tornado affected regions and others. Information can be entered through the e-monitoring system in specific places of the system, so that the appropriation and regulation of funds can be distributed through the e-monitoring system where Government can control as well as allocate funds properly for controlling poverty in West Bengal.

Our target is to remove poverty first as it is the most significant factor for not getting involved into higher education, then the concentration will be there to establish e-learning in West Bengal so that the reasons of less enrollments, as specified by the students, can be resolved.

As compared to the scenarios of web portals of Universities of West Bengal, the implementation of e-learning is not at all satisfactory. [2]

Today's higher education in internationally repute universities is following the pedagogical approaches through e-learning education, as the pedagogical value through web based learning helps the intended students to acquire proper knowledge and skill sets.[3] But the scenario is completely different in West Bengal as the universities do not follow the education through e-learning. The average presence of e-learning attributes of educational websites of the countries i.e. Australia, USA and India especially West Bengal are considered. Some standard characteristics or properties of e-learning systems in web portal are considered like: P1, $\mathrm{P} 2 \ldots \mathrm{P} 23$, where there are the respective properties. [4][5][6][7]

P1--> e-learning materials

P2--> online examination

P3--> online payment

P4--> computer-based training

P5--> web-based training

P6--> instructor-led training

P7--> online registration

P8--> online career counseling

P9--> web conferences

P10-->online helpdesk

P11-->study link to grow more

P12-->e forum

P13-->courses at per industry standard

P14-->Group email for learners

P15-->campuses in remote places to engage rural students

P16-->online competitions like e-debates

P17--> Online news to students regarding higher education

P18-->online career workshops

P19-->Intellectual Property Virtual Scholar Program

P20-->blended learning

P21-->mobile learning

P22-->Digital library

P23-->Digital Question paper access system

Firstly in TABLE III, A1 to A5 represents university's e-learning web portals of Australia; secondly in TABLE IV, U1 to U5 represents university's e-learning web portals of America and thirdly in TABLE V, W1 to W5 represents university's e-learning web portals of West Bengal. Through e-learning it may be possible to enhance the enrollments in higher education as it has been noticed that in those counties where education through e-learning has been applied enrollments have been increased. Still, the bottle neck is poverty in West Bengal, for which the interested students are also unable to go for higher education.

From the TABLE III, TABLE IV and TABLE V, it is shown that USA is having 14 as value unit in support of e-learning in their e-learning enabled university web portals, where as AUSTRALIA is having 13.6 unit in support of e-learning in their e-learning enabled university web portals and WEST BENGAL is having 4.6 unit in support of e-learning in their e-learning enabled university web portals out of 23 components of e-learning.

Moreover, Panigrahi, Das, Basu narrated the presence of a linear regression between gross enrollment ratio (GER) and 
the e-learning enabled higher education system and established that electronic learning is the best alternative through which enrollments in higher education can be enhanced. [2]

From feedbacks of students of rural below secondary students it is shown that only $54 \%$ students are willing to go for higher education through traditional systems of higher education where as when they are explained about the merits and advantages of e-learning based education, $76 \%$ students opined to go for the e-learning based higher education. [1]

TABLE III: UNIVERSITY E-LEARNING WeBSITES’ STATUS IN AUSTRALIA

\begin{tabular}{|l|c|c|c|c|c|}
\hline \multicolumn{1}{|c|}{ Properties } & A1 & A2 & A3 & A4 & A5 \\
\hline P1 & P & P & P & P & P \\
\hline P2 & P & P & P & P & P \\
\hline P3 & P & P & P & P & P \\
\hline P4 & 0 & 0 & P & 0 & P \\
\hline P5 & P & P & P & P & P \\
\hline P6 & 0 & P & P & P & 0 \\
\hline P7 & P & P & P & P & P \\
\hline P8 & 0 & P & P & P & P \\
\hline P9 & P & P & P & P & P \\
\hline P10 & P & P & P & P & P \\
\hline P11 & P & P & 0 & 0 & 0 \\
\hline P12 & P & P & P & P & P \\
\hline P13 & P & P & P & P & P \\
\hline P14 & P & P & P & P & P \\
\hline P15 & 0 & 0 & 0 & 0 & 0 \\
\hline P16 & 0 & 0 & 0 & P & 0 \\
\hline P17 & P & 0 & 0 & P & P \\
\hline P18 & P & 0 & 0 & P & P \\
\hline P19 & 0 & 0 & 0 & 0 & 0 \\
\hline P20 & 0 & 0 & 0 & 0 & 0 \\
\hline P21 & 0 & 0 & 0 & 0 & 0 \\
\hline P22 & 0 & 0 & 0 & 0 & 0 \\
\hline P23 & 0 & 0 & 0 & 0 & 0 \\
\hline Presence & $\mathbf{1 3}$ & $\mathbf{1 3}$ & $\mathbf{1 3}$ & $\mathbf{1 5}$ & $\mathbf{1 4}$ \\
\hline Average & $\mathbf{1 3 . 6}$ & & & & \\
\hline
\end{tabular}

TABLE IV: UNIVERSITY E-LEARNING WEBSITES' STATUS IN USA

\begin{tabular}{|l|c|c|c|c|c|}
\hline \multicolumn{1}{|c|}{ Properties } & U1 & U2 & U3 & U4 & U5 \\
\hline P1 & P & P & P & P & P \\
\hline P2 & P & P & P & P & P \\
\hline P3 & P & P & P & P & P \\
\hline P4 & 0 & 0 & 0 & 0 & P \\
\hline P5 & P & P & 0 & 0 & P \\
\hline P6 & P & P & 0 & 0 & P \\
\hline P7 & P & P & P & P & P \\
\hline P8 & P & P & P & P & P \\
\hline P9 & P & P & 0 & P & P \\
\hline P10 & P & P & P & P & 0 \\
\hline P11 & P & P & P & 0 & 0 \\
\hline P12 & P & P & 0 & 0 & 0 \\
\hline P13 & P & P & 0 & P & 0 \\
\hline P14 & P & P & P & P & 0 \\
\hline P15 & 0 & 0 & 0 & 0 & 0 \\
\hline P16 & 0 & 0 & 0 & 0 & 0 \\
\hline P17 & P & P & 0 & 0 & 0 \\
\hline P18 & P & P & 0 & 0 & 0 \\
\hline P19 & 0 & P & 0 & 0 & 0 \\
\hline P20 & 0 & 0 & 0 & 0 & P \\
\hline P21 & 0 & 0 & 0 & 0 & P \\
\hline P22 & 0 & 0 & P & 0 & 0 \\
\hline P23 & 0 & 0 & 0 & 0 & 0 \\
\hline Presence & $\mathbf{1 4}$ & & & & \\
\hline Average & & & $\mathbf{9}$ & $\mathbf{9}$ & $\mathbf{1 1}$ \\
\hline
\end{tabular}

TABLE V: UNIVERSITY E-LEARNING WEBSITES’ STATUS IN WEST BENGAL

\begin{tabular}{|l|c|c|c|c|c|}
\hline Properties & W1 & W2 & W3 & W4 & W5 \\
\hline P1 & P & 0 & 0 & 0 & 0 \\
\hline P2 & 0 & 0 & 0 & 0 & 0 \\
\hline P3 & 0 & 0 & 0 & 0 & 0 \\
\hline P4 & 0 & 0 & 0 & 0 & 0 \\
\hline P5 & 0 & 0 & 0 & 0 & 0 \\
\hline P6 & 0 & 0 & 0 & 0 & 0 \\
\hline P7 & 0 & 0 & 0 & P & P \\
\hline P8 & 0 & 0 & 0 & P & P \\
\hline P9 & 0 & 0 & 0 & 0 & 0 \\
\hline P10 & 0 & P & 0 & P & P \\
\hline P11 & P & P & P & P & P \\
\hline P12 & 0 & 0 & 0 & 0 & 0 \\
\hline P13 & P & 0 & 0 & 0 & 0 \\
\hline P14 & 0 & P & 0 & 0 & P \\
\hline P15 & 0 & 0 & 0 & 0 & 0 \\
\hline P16 & 0 & 0 & 0 & 0 & 0 \\
\hline P17 & P & 0 & 0 & 0 & 0 \\
\hline P18 & P & 0 & 0 & 0 & 0 \\
\hline P19 & 0 & 0 & 0 & 0 & 0 \\
\hline P20 & 0 & 0 & 0 & 0 & 0 \\
\hline P21 & 0 & 0 & 0 & 0 & 0 \\
\hline P22 & P & 0 & 0 & P & P \\
\hline P23 & P & 0 & 0 & P & 0 \\
\hline Presence & $\mathbf{7}$ & $\mathbf{3}$ & $\mathbf{1}$ & $\mathbf{6}$ & $\mathbf{6}$ \\
\hline Average & $\mathbf{4 . 6}$ & & & & \\
\hline & & & & \\
\hline
\end{tabular}

\section{CONCLUSION}

In this paper it can be concluded that by eradicating poverty it is possible to remove one of the key factors of less enrollments in higher education. Through electronic monitoring of complaints and feedbacks from region specific blocks it is possible to point out where the funds are to be allocated and for which purpose. And, e-learning is the best way out to engage the higher education aspiring students enrolled to it and that will lead to the overall enhancement of GER of West Bengal.

\section{REFERENCES}

[1] A. Das, D. K. Banerjee, and K. Basu, "Implementation of E-Learning in West Bengal to Enhance the Present GER in Higher Education," International Journal of Innovation, Management and Technology, Vol. 2, No. 3, June 2011

[2] G. Panigrahi, A. Das, and K. Basu "A study to increase effectiveness of distance learning websites in India with special reference to the state West Bengal to increase the present GER of higher education through incorporation of Elearning facility in a better way," Procedia Social and Behavioral Sciences 15 (2011) 1535-1539 2011.

[3] T. K. Sen, "Blended Learning in Course Delivery and the Student."

[4] "Learning Experience" International Journal of Innovation, anagement and Technology, Vol. 2, No. 2, April 2011.

[5] J. Palmer. Website usability, design, and performance metrics. Inform. Systems Res. 13(2) 151-167, 2002

[6] J. Eighmey. Profiling user responses to commercial web sites. Journal of Advertising Research. 37(3) 59-66, 1997

[7] R. Agarwal, V. Venkatesh. Assessing a firm's Web presence: A heuristic evaluation procedure for the measurement of usability. Inform.Systems Res. 13(2) 168-186, 2002.

[8] S. Ghose and W. Dou. Interactive functions and their impacts on the appeal of Internet presence sites. Journal of Advertising Research. 38(2), 1998. 


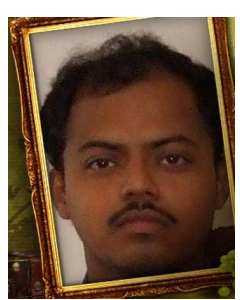

Mr. Anirban Das is pursuing his research work in the Department of Mathematics from National Institute of Technology, Durgapur, India. He is having around 4 years of work experience including academics and industry. He started his career with HCL Technologies as a software Engineer. He is Microsoft Certified Technology Specialist (MCTS) in Microsoft Office Sharepoint Server 2007. Presently he is Assistant Professor in Computer

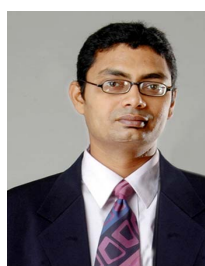

Mr. Subir Gupta is an Assistant Professor of department of Computer Applications in Dr. B. C. Roy Engineering College, Durgapur. Having about 9 years of experiences in academics, he was associated with academic institutions in Orissa and presently in West Bengal. Mr. Gupta's research interests cover Statistical Analysis, e-monitoring, e-learning, software engineering and computer applications.

Applications department in Dr. B. C. Roy Engineering College, Durgapur India. He has around 13 research papers in various eminent journals and conferences. Mr. Das has interests in Statistical Analysis, e-commerce, e-learning and computer applications as domain of research. 